\title{
Human Resources in Public ADMinistration - CURRENT CHALLENGES AND EXPECTATIONS (THE POLISH-LOWER SILESIAN PERSPECTIVE)
}

\author{
JERZY KORCZAK*
}

\section{INTRODUCTION}

The issue of administration personnel continues to be valid in research into public administration, especially in the research area of administration studies. The reason is that we are increasingly beginning to recognize that the execution of public administration tasks is effected by its personnel's actions. The personnel holds positions of monocratic bodies and participates in the operations of collegial bodies as is the case in a local selfgovernment. Obviously the selection of councillors of bodies making up local self-government units or the appointment, selection or another form of creation for positions of province governors or ministers results from processes of democratic creation of power bodies where questions about professional qualifications are not always justified (voters are not always guided by an eligibility criterion) whereas employment in public administration and organizational units, especially in civil service positions, should follow a careful selection of candidates for the relevant positions.

When conducting any deliberations on public administration personnel I often refer to a quotation from T. Górzyńska's dissertation: "Legitimate theoretical assumptions, good law, thought-out structures and meticulously developed working methods will practically turn really efficient only if they are effected by a personnel that understands the essence and objectives of public service, a personnel that is professionally and morally prepared for the assigned tasks" ". The date of this statement is worth underlining - 1985 - i.e. 30 years ago, the days when Poland was part of the so-called people's democracies camp and followed a socialist state regime no matter how abstract and culturally alien to its citizens were the system's ideological assumptions taken, given the society's tradition of fostering a system of values absolutely at odds with the ideology's values.

DOI: $10.1515 /$ wrlae-2015-0050

* Prof. University of Wroclaw PhD in Law, Head of Department of Administration Science at the Institute of Administrative Sciences, Faculty of Law, Administration and Economics, University of Wrocław; jerzy.korczak@uwr.edu.pl

${ }^{1}$ Teresa Górzyńska, Stanowiska kierownicze w administracji państwowej. Zagadnienia prawne [Managerial Positions in State Administration. Legal Issues] (Ossolineum 1985) 70. 
In those days the personnel selection was subject to equally ideological assumptions $^{2}$ and T. Górzyńska's statement clearly deviated from the stereotypes of the day. However, the system's transformation of the early 1990 s in the democratic state of law unfortunately did not at all invalidate its relevance and helpfulness.

This obviously causes one to ask questions about the reasons for such a state of affairs given Poland's democratic rule of law system today in which ideological considerations should give way to the legal order. In my view the reasons are twofold in nature: legal and sociological. The first refers to the condition of the law that sets forth employment regulations in public administration. The second refers to convictions about bloated public administration structures and personnel which are deeply rooted in the society's mindset. And both stem from the conscious actions of people actively involved in shaping the country's policy. Over the past twenty five years Poland's democratic system has seen the country's political decision makers either fail to look into the condition of the legal regulations at all $^{3}$ or made it a point of serious political disputes ${ }^{4}$ or blatantly made it an instrument for getting at hasty political objectives. ${ }^{5}$

\footnotetext{
${ }^{2}$ Criteria such as a guarantee to perform an employee's duties diligently on account of an ideological and moral level prevailed in the regulations of acts providing the foundations of employment in the-then state administration, see art $11 \mathrm{sec} 4$ of 15 July 1968 Act on national councils employees (Dziennik Ustaw - Official Journal of Laws of the Republic of Poland (hereinafter: Dz. U.) No 25, item 164), also para ordinance of the Council of Ministers dated 20 December 1974 on the rights and duties of employees of state offices (the Dz. U. No 49, item 300), in a just a little amended wording art 3 point 4 of Act of 16 September 1982 on employees of state offices (Dz. U. 2013, item 269).

3 The Act of 16 September 1982 on employees of state offices (Dz. U. 2016, item 1511) provides an example. Despite the archaisms of terms used herein, very often not referring at all to existent bodies and offices of public administration, to a large extent dead and not performed and despite an evident need to provide modern regulations of employing state employees has not been replaced by a contemporary comprehensive legal regulation apart from fragmentary amendments.

${ }^{4}$ Our politicians needed 6 years to develop the form of the Polish civil service. Even though preparations took off as early as in 1990 the Act on Civil Service was adopted only on 5 July 1996. Hardly had it become binding when it was amended with a new act on account of a political scandal arising from appointments of director generals of government administration offices not in accordance with the Act's provisions. See Jerzy Korczak, 'Kadry administracji publicznej wobec przeobrażeń we współczesnym prawie administracyjnym' [Public administration human resources and changes in contemporary administration law] in Adam Błaś (ed), Współczesne problemy administracji publicznej $i$ prawa administracyjnego. Materiaty $z$ sesji naukowej na temat przeobrażeń we współczesnym prawie administracyjnym [Contemporary public administration and administration law issues. Materials from a research session on changes in contemporary administration law] - Wrocław, November 1997 (Terra 1999) 43-56.

${ }^{5}$ The amended Act on Civil Service of December 2015 provides an example - the Act of 30 December 2015 on amending the Civil Service Act and some other acts (Dz. U. 2016, item 34) that were aimed at getting rid - from government administration offices - of people holding senior positions in civil service and transferred to those positions in the past i.e. when today's opposition was in power. See on this issue Jerzy Korczak, 'Antywartość w prawie administracyjnym jako zamierzony skutek legislacyjny' [Anti-value in administration law as an intended legislative measure] in Adam Błaś (ed) Antywartość w prawie administracyjnym [Anti-value in administration law] (Lex a Wolters Kluwer business 2016).
} 


\section{The Characteristics of the Polish Civil Service LaW}

It should be stressed most importantly that since World War II Poland has never returned to the civil service model most common in Europe, a model of a public service career treating civil service law as a law of a public organization of the administrative personnel and using a corps system to this end. At the same time Poland did not adopt the Anglo-Saxon model of positional employment but developed its own intermediate model between the two models. This resulted in treating civil service law as part of the labour $\operatorname{code}^{6}$, without it being subject to the general act though, i.e. the Labour Code; however, with numerous scattered and incomplete regulations-wise - official civil service pragmatics.

This makes them unsustainable acts because each example of pragmatism in a certain part of the employment of officials requires the application of either the regulations of the Labour Code or other acts of the administrative constitutional ${ }^{7}$ or substantive law ${ }^{8}$. If we take into account the public administration system that - despite the unitary character of the state - divides it into three fundamental sectors: state administration, centralized government administration and decentralized administration that additionally is divided into local self-government administration and that of economic and professional self-governments. The state administration is not related to the government. At its most it is subject to parliamentary control ${ }^{9}$, however, it does not have a common superior, which makes each of its bodies have a separate legal regulation and the regulations of the aforementioned act on state offices employees apply to those employed only to a small degree. Despite being centralized under the authority of the Prime Minister the government administration is internally diversified because, apart from those employed in civil service positions within the framework of employment relationships, there are officials employed within the framework of service relationships ${ }^{10}$. In addition, the group employed within the framework of employment relationships is divided into civil service corps and foreign service corps.

\footnotetext{
${ }^{6}$ Act of 26 June 1974 - Labour Code (Dz. U. 2016, item 1666).

${ }^{7}$ For example, the status of the city mayor in Poland is regulated by as many as three acts: the Act of 21 November 2008 on self-government employees (Dz. U. 2016, item 902) i.e. self-government civil service pragmatics; the Act of 8 March 1990 on municipal selfgovernment (Dz. U. 2016, item 446 as amended) i.e. political system act; and the Act of 5 January 2011 - Electoral Code (Dz. U. 2011, No 21, item 112 as amended) i.e. electoral law.

${ }^{8}$ For example, the status of the county construction supervision inspector is regulated by the Act of 21 November 2008 on civil service (Dz. U. 2016, item 1345 as amended) i.e. civil service pragmatics as well as the Act of 7 July 1994 - Construction Law (Dz. U. 2016, item 290) i.e. substantive law act; in turn, the status of the provincial conservator-restorer is also regulated by civil service pragmatics - act on civil service - as well as substantive law - the Act of 23 July 2003 on monument protection and monument care (Dz. U. 2014, item 1446 as amended).

${ }^{9}$ For example, General Inspector of Personal Data Protection, or the Ombudsman.

${ }^{10}$ For example, officials of Police, State Fire Brigade, Border Guard, Prison or Special Services: Central Anti-corruption Office, Home Security Agency, Home Intelligence Service, Foreign Intelligence Service, Military Intelligence Service, Military CounterIntelligence Service, etc.
} 
Finally, within the civil service corps there are varieties related to belonging to the general administration under the authority of province governors and specialist administration. The local self-government administration's feature is primarily the independence of communes, counties and provinces of one another. Consequently, employment occurs in the area of a given unit even though the regulations of the self-government pragmatics make it possible to transfer officials between units upon the mutual agreement of managers of particular organizational units. As far as the administration of economic and professional self-governments is concerned, there are no civil service positions and functions in the selfgovernment bodies are performed without establishing an employment relationship.

In contrast to the traditional model of the civil service career whereby on account of the public and legal nature of the civil service position employment was effected in the main on the basis of the nomination, the Polish civil service law model is characterized by a multiplicity of legal forms of establishing an employment relationship; only service relationships are established on the basis of acts of nomination and acts of appointment. For officials employed within the framework of the employment relationship the following acts are applied: acts of selection ${ }^{11}$, acts of appointment ${ }^{12}$, acts of nomination ${ }^{13}$ and employment contracts ${ }^{14}$.

Attention should be drawn to the fact that relevant regulations of the Civil Code introduce a notion of the presumption of an employment contract as a form of establishing an employment relationship, whereas for the remaining acts identifying each of them in the given pragmatics ${ }^{15}$ is required. This - amidst those employed in public administration in general (not taking into account the aforementioned differentiations) - results in the group employed within the framework of the employment contract prevailing absolutely over the other groups differentiated on account of their employment model. It should be noted that,whereas a transfer of a civil

\footnotetext{
${ }^{11}$ The following are employed through an election act: heads of rural communes, mayors of towns and presidents of cities, district governors and other members of county management boards and marshals as well as other members of province offices management boards.

12 Applicable for filling positions of managers of central government administration offices, province governors as well as treasurers of communes, counties and province offices and deputies of heads of rural communes, mayors and presidents of cities.

${ }^{13}$ Quite rarely for some government officials, but primarily civil servants; since 2009 there have been no nominated officials in a local self-government.

${ }^{14}$ Fundamentally, this form prevails in state administration, government administration (corps members not being part of the civil service corps) and self-government administration offices.

${ }^{15}$ Provision of art 68 para 1 stipulates that an employment relationship is established on the basis of an appointment in cases set forth in separate provisions and so stipulates art $4 \mathrm{sec} 1$ point 2 of self-government pragmatics. Provision of art 73 para 1 stipulates that an employment relationship on the basis of an election is established when an obligation to carry out work as an employee results from the election and on account of this art 4 para 1 point 1 of self-government pragmatics lists the aforementioned holders of executive bodies of local self-government units as self-government officials employed on an election basis. In turn, provision of art 76 stipulates that an employment relationship is established on the basis of nomination in cases set forth in separate provisions and art 3 point 2 in relation to art 49 of civil service pragmatics.
} 
service corps employee from the employment contract category to a civil service nomination category as a result of the successful passing of the relevant qualification proceedings ${ }^{16}$ is possible only in the civil service corps as far as self-government employees are concerned despite the presupposed para 20 of the self-government pragmatics in-house promotion, which may consist in a transfer from a public administration employee position to a managerial public administration position; however, this does not entail a change to the form of establishing an employment relationship since the two categories of positions are covered by the same employment form.

The state of the regulations of the Polish civil service law characterized this way is not conducive to appropriate personnel recruitment and its further development, notably when the above is aggravated by considerations of political nature and unavoidable pathological phenomena (nepotism, the dishonesty of recruitment team members). Sociological conditions pointed out in the early paras add to its negative characteristics. Their general undertones are a critical approach to the administration as such and to its representatives - employees and officials holding positions in the public administration bodies in particular. They do not arouse the trust of society ${ }^{17}$ and are often abused by politicians being blamed for the failures of political programmes and initiatives regardless of whether an individual official is in a position to hamper the delivery of the programme or make up for the politicians' faults.

\section{ANALYSIS OF EMPLOYMENT DATA AND DEMOGRAPHIC Structures of Public Administration Personnel in Poland}

There is a dispute regarding the number of those employed in public administration in Poland as well as in other countries. The dispute is between those who think that the number is too high and has been on the increase and those who believe that the number is not adequate to meet social needs, which is reflected in queuing applicants waiting a long time for their matters to be formally completed. This dispute is of the insoluble type as there are no appropriately established statistical research methodologies that help unequivocally calculate the number of people employed in public administration in civil service positions since objective selection criteria are non-existent due a different classification of positions set forth by each public administration act. Consequently, the Central Statistical Office most often gives employment data in the public sector and only then the number of those employed in particular sectors of the state, government and local self-government administrations. However, these data are not accurate. In turn, those that claim bloated personnel use a term 'official' to denote

\footnotetext{
${ }^{16}$ See paras $40-51$ of civil service pragmatics.

${ }^{17}$ For further info on this issue see Jerzy Korczak, 'Pozyskiwanie i umacnianie zaufania do władz publicznych przez współadministrowanie' [Winning and enhancing trust in public authorities through co-admininstration] in Małgorzata Stahl, Michał Kasiński, Katarzyna Wlaźlak (eds), Sprawiedliwość i zaufanie do władz publicznych w prawie administracyjnym [Justice and trust in public authorities in administration law] (Lex a Wolters Kluwer business 2015) 98-114.
} 
anyone employed in public administration and fail to remember that apart from a person employed in a civil service position we often come across a front desk person looking after the city's green areas or funeral services.

In 2014 the number of people employed in the whole public sector stood at 3 million. In the government and state administrations it was over 440000 people, in the local self-government it was 260000 people. These data are set against 1989 i.e. the beginning of the system's transformation, the days when the state administration employed 160000 people. Such a juxtaposition is flawed. Firstly, any statistical data from the socialist state days are not reliable. Secondly, the distinctness of the public administration's system - uniform and centralized at the time and in stark contrast to today's decentralised one - is not taken into account. Thirdly, the growth of the public services sector arising from new social needs and stemming from new technological innovations is not taken into account. And fourthly, some tasks of the contemporary public administration had been done by the so-called public utilities not listed at the time in the state administration. Journalists and other public debate participants cite - in their discussions about the state of Poland's state administration - examples of other European countries where employment in public administration has fallen by about 800000 across the European Union over the past few years. They fail to quote the sources of these data or the methodology of their aggregation, though. Poland has seen diversified processes in employment level changes. The reason is that on the one hand employment in the government administration has been falling and on the other hand it has been on the increase in the self-government administration. Consequently, it is impossible to judge the phenomenon in an unequivocal manner.

The number of public administration offices as potential employers of officials should be taken into account. The number is a function of the legal regulations appointing particular administration bodies and the offices serving them (contrary to some views, offices are not created at random nor is it a spontaneous process). The state's central level features 24 ministries ${ }^{18}$ and over 80 state and government offices ${ }^{19}$. Provinces boast 16 province offices and an appropriate number of offices of territorial bodies within divisions of central bodies having its own territorial structures. In addition, there are self-government offices (16 province marshal offices). Then, apart from 314 districts on the county level, there are an appropriate number of general county government administration bodies under the authority of a district governor and specialist ones (county vets). Finally, there are communes and municipalities in 2478 communes. If we add to that simple territorial and constitutional scheme bodies of atypical territorial structures (e.g. sea offices, mining offices and the like) the number of a few dozen thousand offices does not seem to be excessive or unjustified. However, it should be taken into account that apart from the classical administrative office there are many organizational units in administration that employ in

\footnotetext{
${ }^{18}$ Their number is dependent on ordinance issued by the Prime Minister on the basis of art 33 para 1 of 8 August 1996 Act on the Council of Ministers (Dz. U. 2012, item 392 as amended).

${ }^{19}$ Each of them have a separate act basis.
} 
civil service positions. Employment in these offices is not a constant given natural fluctuation and a consistent fall in employment in government administration and a simultaneous growth of its level in self-government administration. Still, both fluctuations and a host of other processes affecting the state of the personnel have been giving rise to doubts regarding their adverse effect on the efficiency of public administration.

The first one is a fall in employment in general. In just the civil service corps 3700 members have left since 2010. At the same time the total number of civil service positions has dropped by 1155 and stood at 119300 towards the end of 2015. As much as 38\% of offices reduced employment; the IRS administration itself cut 748 positions. Fluctuation is another phenomenon that in 2015 only stood at $7.3 \%$; in some offices it went up to over $20 \%$.

In parallel a decreasing attractiveness of being employed in the civil service corps can be seen. This shows that working within this elite civil personnel is not attractive at all. 2015 saw another fall in the number of applicants per vacancy, down to 19 applicants on average. Back in 2013 the number was 36 and in 2014 it stood at 24 applicants per vacancy. The ever decreasing attractiveness of employment in civil service positions in government administration results in a lower number of applications of young people i.e. up to 30 years of age $(10.4 \%$ in 2014 down to $9.0 \%$ in 2015). The number of applicants aged 31-50 has been on the increase (from $57.4 \%$ in 2014 up to $59 \%$ in 2015). The number of applicants aged 51-55 has decreased by $1 \%$ down to 30.8 . It has remained unchanged for applicants over 65 and has stood at 1.2\%. In 2015 despite these trends 5000 people took up employment in civil service positions for the first time, which is a substantial increase compared to the past years and making up $73 \%$ of people employed in vacant positions within the framework of the selection process.

Moreover, the structure of those employed in the civil service corps is deteriorating as far proportions between its members and civil servants are concerned. As previously pointed out in line with art 3 of the act the corps is fundamentally divided into two categories of people employed in civil service positions: civil servants employed on the basis of an employment contract and nominated civil servants - on account of a low number of nominated civil servants maintained over the past years, the number of civil servants does not go beyond $6.5 \%$ of the total corps members ( 7745 jobs). Out of the total number of 119000 employed in civil service positions 12345 are ministry officials (even though out of these 2517 only are nominated officials), 10926 are officials within central offices (here 625 are nominated officials), 8578 are officials of provincial offices (among them 642 are nominated), 14823 are officials of general administration in the province (with 203 nominated), 8615 are officials of general administration in the county (with only 22 nominated), 40920 are IRS administration officials (with 2150 nominated officials) and 4963 officials in IRS control units (among them 924 are nominated). The remaining specialist administration employs 16842 officials (including 351 nominated) and the diplomatic corps employs 1245 (with 311 nominated). The nomination of a civil servant is dependent first of all on the quotas set in the budget act of a given year, which for 2015 meant 200 people. 36 
KSAP (National School of Public Administration) graduates applied. They were nominated in the statutory manner. Out of 828 applicants (in 2014 880) 291 successfully completed the recruitment stages, which resulted in the final nomination of 162 successful applicants (this means that 2 nominated civil service positions were not filled).

The gender employment structure is also getting worse. The corps is feminized $-70 \%$ of those employed are women. Women also occupy 53\% of senior positions.

Despite regulations friendly for employing the handicapped their employment level is low and stands at 3.9\%. Nevertheless, there are single offices boasting as much as $12 \%$.

In 2009 art 4 of the Civil Service Act was amended with a reservation that a Polish citizenship requirement to be eligible for membership in the corps is not absolute. Art 5 stipulated that citizens of EU member states as well of as other states with which Poland signed relevant bilateral agreements can be employed in civil service positions identified by the General Director of the Office. Consequently, an influx of the corps members of those countries was expected. Indeed in 210510 foreigners applied for vacant civil service positions; however, only 1 of those was employed.

\section{ANALYSIS OF EMPLOYMENT DATA AND DEMOGRAPHIC Structures of Public Administration Personnel in Lower SILESIA}

Against the backdrop of the country-wide data the Lower Silesian situation does not deviate from general trends seen in the other regions. It should be remembered that the government administration exclusively on the level of the province and the county in parallel to the provincial and county self-government is operating in the Lower Silesian province. The communes have a commune self-government only. This is why employment in public administration will concern only employment in offices and organizational units of the government administration as well as offices and organizational units of the local self-government. There are 26 counties and 4 towns with county rights in the province (Wrocław, Wałbrzych, Legnica and Jelenia Góra). Within this territorial structure in the government administration there is 1 Lower-Silesian Province Governor's Office along with its 3 subsidiaries (in Wałbrzych, Legnica and Jelenia Góra) and accordingly provincial Police and State Fire Brigades inspectorates, provincial inspection bodies, IRS and customs chambers, in addition subsidiaries and branches of central state offices (e.g. the Supreme Audit Office, the National Labour Inspectorate), in addition at the county level there operate relevant county police stations, inspectorates and fire brigades as well as 34 IRS offices. As far as self-government administration is concerned it is evident that 1 Lower Silesian Province Marshal's Office 
along with multiple organizational units ${ }^{20}, 26$ districts and 169 municipalities should be taken into account. 46065 people were employed in these offices and organizational units in 2015. In relation to the 2005 count of 41701 this represents an increase of 10.5\%. The number includes 14435 employed in the state administration, 11040 employed in the government administration and 20582 employed in the self- government administration. Each sector of the Lower Silesian public administration has seen a different dynamic of its employment structure. The number employed in the state administration has not seen fundamental changes. The number employed in the government administration has seen a drop of $7 \%$ over the past 5 years. Employment in the self-government administration has grown by $3 \%$. The counties have seen a drop of nearly $5 \%$ whereas the province has seen a growth of $20 \%$.

Only a more detailed analysis of the statistical data reveals a complete picture of the processes taking place in the condition of the Lower-Silesian personnel. An issue of ever decreasing attractiveness of public administration jobs is confirmed. 7884 people were employed in 2005 in contrast to only 5382 in 2015 . It should be noted that from among those employed a group previously employed was dominant since a bare 665 people were employed for the first-time and from among those 383 were graduates. If we juxtapose this number against data of annual LowerSilesian graduates the result of this juxtaposition is worrying.

This leads to an analysis of the employment structure in public administration in terms of employment level. According to 2104 data made available by the Statistical Office of Wroclaw the Lower Silesian administration had 344 employees boasting a $\mathrm{PhD}$ or higher degree, 18918 employees with a Master's or equivalent degree, 3928 employees with a Master of Science in Engineering or Bachelor's degrees. In the same period 1527 undergraduates were employed in the administration, 4678 with secondary vocational education and 17772 with secondary education. Apart from civil service positions - in auxiliary and service positions - there were also employed 1337 people with a vocational education and 521 people with gymnasium and primary or incomplete primary education. It should be remembered that civil service positions must not be occupied by people below secondary, vocational or lycee level education.

An issue of feminised personnel is also confirmed. Women made up $66.1 \%$ of the total 46000 employed. Women also prevailed among those newly-employed in $2015-58.9 \%$ among those taking up employment for the first time about $60 \%$, and among those also graduates i.e. $73 \%$.

The aforementioned processes of the ever decreasing attractiveness of employment in administration and a falling number of graduates taking up first employment in administration also affect the structure of age

\footnotetext{
${ }^{20}$ The list included in the Public Information Bulletin encompasses the Lower Silesian List of Wildlife Parks, the Lower Silesian Road and Railway Service, the Lower Silesian Board of Melioration and Water Facilities, Territorial Development Institute, the Lower Silesian Office of Geodesy and Agricultural Areas, the Regional Office of the Province of Lower Silesia in Brussels, the Province of Lower Silesia Labour Office in Wałbrzych, the Lower Silesian Social Policy Centre, , the Lower Silesian Mediation Institution, 4 Provincial Traffic Centres, the Lower Silesian Agricultural Consultancy Centre, and 13 schools, 6 pedagogical libraries, 4 teacher education centres and 4 educational centres, 17 cultural institutions and a few dozen medicare entities.
} 
brackets of Lower Silesian officials. According to data made available by the Wroclaw Statistical office towards the end of 2014 the most numerous group were officials aged 55-59 (5 676), then officials aged 35-39 (5 250), followed by officials aged 30-34 (4 850), 40-44 (4 469) and 50-54 (4 360). These were followed by officials aged 45-49 (3 646) and two age groups of 25-29 (2 128) and 60-64 (2 059). The least numerous were two boundary age groups: 20-24 (323) and over 65 (264).

The aforementioned fluctuation issues - signaled across the country as a weakness of the legislation that does not tie an official to the administration for their entire professional career which was the case in the early stages of the civil service law in the Prussian professional career model - can also be seen in Lower Silesia. In 2015 employment relationships were terminated with 8806 officials (including 3187 women). Given that 5382 officials were newly employed in 2015 an overall fall in the number of employed is evident, a point already made. The analysis of the reasons for an employment freeze leads to the following findings. Out of the total number of terminated employment relationships 3640 were terminated by an employer, 297 were terminated by an official, 106 were terminated due to certification of incapacity for work and 831 were related to retirement. Maternity leaves also affected the employment numbers (208 officials, almost $100 \%$ by women). The employment and terminations statistics results in a high differentiation of employment tenures in administration. The most numerous group -9576 officials - has the longest tenure i.e. at least 30 years; nearly half the size -5205 officials - is covered by a 5-10 years' tenure group, followed by the following tenure groups: 1015 years (4 560 officials), 15-20 years (4 151 officials), 20-25 years (3 657 officials) and 25-30 years (3 550 officials); finally 2-5 years (1 399 officials) and the least numerous group - 927 officials - with a tenure of up to 2 years. The above analyses show that groups of officials fundamentally match age groups in terms of tenure. Consequently, the most senior officials are the most numerous group. They began their professional career still in the administration of the socialist country, a country that was centralized and founded on ideological foundations rather than legal ones. It is they who are identified as creating a negative administration image. Even though they are most apt at performing their office duties they are loaded with habits ingratiated from the early days of their employment when their professional attitudes were being shaped i.e. a typically authoritarian treatment of a citizen as an applicant rather than a client or a public service customer.

To illustrate the aforementioned process one can cite the case of the Lower Silesian Province Marshal's Office. Towards the end of October 2016 there were 1011 jobs; 1028 officials were employed, which represents an increase of $2 \%$ in relation to the status of 2015 year end. Similar to the aforementioned analyses of the public administration HR condition this office also employs more women (761) than men (268). Their qualifications are mostly high (980 officials) against 48 officials with secondary education and 1 official with vocational education. The age structure is as follows: 506 officials aged 31-40, 220 officials aged 41-50, 122 officials aged 20-30 and 121 officials aged 51-60, finally 60 officials aged over 60. Within 2016 there were announced 71 recruitments for 74 
vacant civil service positions, including managerial positions. 42 selections were completed till the end of October. 36 people were identified for employment. 29 selections were due to be completed till the end of 2016. The Office job attractiveness is clearly dependent on the position's place in the hierarchy and job description. For example, a record 24 applications were filed for a position of Specialist in Waste Water Management Department within the Environment Division. In contrast, not a single application was filed for a position of Chief Specialist in the Applications Department within the IT Division. ${ }^{21}$

For comparison, 183 job announcements were made in the Lower Silesian Province Office in 2016. Out of these 158 were completed, 23 are ongoing and 2 announced in December. Out of 158 selections 113 people were identified for employment; however, 4 of them gave up on an employment, in 4 cases the recruitment was cancelled, in 7 cases no applications were filed and in 4 cases the applicants did not meet formal eligibility criteria. Failing to meet the formal eligibility criteria through announcements about the results of the recruitment results on BIP DUW website makes it impossible to evaluate the recruitment frequency.

\section{CONCLUSION}

The paper presented the legal conditions of employment in each public administration sector. Then statistical data on the general condition of employment and the condition of employment in particular sectors across the country and in the Province of Lower Silesia were presented. Demographic data were used. The data enabled an analysis of the employment structure in terms of sex, age brackets and qualifications as well as an analysis of employment fluctuation data. Their appropriate juxtapositions and comparative studies reveal a picture of the condition of the Polish and Lower-Silesian public administration personnel, a not very uplifting picture. Setting aside populist views on allegedly excessive employment and its bloated levels in particular offices and organizational units the personnel presents itself as too feminized (this gives rise to a social perception of the civil service job as being appropriate for a woman rather than a man), outdated (groups advanced in their age prevail) and not attractive enough as an employment offer for young graduates.

A preliminary diagnosis of the reasons for such a state of affairs is not only a layer of the aforementioned sociological conditions but primarily a normative layer of the civil service law regulations. These regulations do not allow for delivering a uniform and comprehensive HR policy. The regulations governing the recruitment for vacant civil service positions are not correct. Neither are ones on in-house promotions and assessment

\footnotetext{
${ }^{21}$ In 3 cases 1 application was filed, in 8 cases 2 applications were filed, in 3 cases 3 applications were filed, in 4 cases 4 applications were filed, in 3 cases 5 and 6 applications were filed, in 5 cases 7 applications were filed, in 1 case 8 applications were filed, in 2 cases 9 applications were filed, in 1 case 10 applications were filed, in 2 cases 11 applications were filed, in 1 case 12 applications were filed, in 2 cases 13 applications were filed, in 1 cases 15 and 18 applications were filed, and in 1 job announcement 21 applications were filed for 2 position.
} 
system. Finally, pay regulations do not create effective incentives to apply for public administration jobs. Due to their scattering and lack of cohesion the civil service regulations are not conducive to creating equivalent employment systems in particular public administration sectors. And last but not least it should be noted that the civil service regulations' weakness is their excessive dependence on political influence even though art 153 of the Constitution guarantees a political neutrality of the civil service corps.

\section{References}

Górzyńska Teresa, Stanowiska kierownicze w administracji państwowej. Zagadnienia prawne [Managerial Positions in State Administration. Legal Issues] (Ossolineum 1985)

Korczak Jerzy, 'Antywartość w prawie administracyjnym jako zamierzony skutek legislacyjny' [Anti-value in administration law as an intended legislative measure] in Błaś Adam (ed), Antywartość $w$ prawie administracyjnym [Anti-value in administration law] (Lex a Wolters Kluwer business 2016)

Korczak Jerzy, 'Kadry administracji publicznej wobec przeobrażeń we współczesnym prawie administracyjnym' [Public administration human resources and changes in contemporary administration law] in Błaś Adam (ed), Wspótczesne problemy administracji publicznej $i$ prawa administracyjnego. Materiały z sesji naukowej na temat przeobrażeń we współczesnym prawie administracyjnym [Contemporary public administration and administration law issues. Materials from a research session on changes in contemporary administration law] - Wroctaw, November 1997 (Terra 1999)

Korczak Jerzy, 'Pozyskiwanie i umacnianie zaufanie do władz publicznych przez współadministrowanie' [Winning and enhancing trust in public authorities through co-admininstration] in Stahl Małgorzata, Kasiński Michał, Wlaźlak Katarzyna (eds), Sprawiedliwość i zaufanie do władz publicznych $w$ prawie administracyjnym [Justice and trust in public authorities in administration law] (Lex a Wolters Kluwer business 2015) 